\title{
REGULARARTICLE \\ ORGANIC FERTILIZATION AND NATURAL SUBSTANCES TREATMENTS AFFECTS CHEMICAL CONSTITUENTS OF GUAR PLANTS
}

\author{
ABEER M. SHEHATA ${ }^{1,2}$, M. A. H. ABDOU ${ }^{2}$, A. A. EL-SAYED ${ }^{2}$, F. A. ATTIA ${ }^{2}$, R. A. TAHA ${ }^{2}$
}

${ }^{1}$ Medicinal and Aromatic Plants Researches Department, Horticulture Research Institute, Agricultural Research Center, Egypt

${ }^{2}$ Horticulture Department, Faculty of Agriculture, Minia University, Egypt

\begin{abstract}
This experiment was conducted at the Floriculture Nursery, Faculty of Agriculture, Minia University during the two successive seasons to study the effect of compost at rates (o, 25, 2.50 and 3.75 ton/fed.) and natural substances i.e. vitamins (ascorbic acid at 50 and $100 \mathrm{ppm}, \alpha$-tocopherol at $10,20 \mathrm{ppm}$ and thiamine, at 25 and $50 \mathrm{ppm}$ ) and active yeast at 2.5 and $5 \mathrm{~g} / \mathrm{l}$. and their interaction on some chemical constituents of guar plants. The results indicated that, Addition of compost caused an increase in guaran \%, Photosynthetic pigments, Total carbohydrates (\%) N, P and K (\%) and Protein (\%). The maximum level in all previous traits was for the plants growing in the soil fertilized with the highest level of compost (3.75 t/fed.). Using the treatments of vit. $\mathrm{C}$ at $50 \mathrm{ppm}$ followed by $5 \mathrm{~g} / \mathrm{l}$. active yeast, then vit. $\mathrm{E}$ at $10 \mathrm{ppm}$ gave the highest values of all previous traits. The interaction between the two main factors $(\mathrm{A} \times \mathrm{B})$ was significant for guaran \%, photosynthetic pigments, total carbohydrates $\%, \mathrm{~N}$ and $\mathrm{P} \%$., The highest values were obtained from the interaction treatments of 3.75 ton/fed., compost in combination with active yeast at $5 \mathrm{~g} / \mathrm{l}$. and vit. $\mathrm{C}$ at $50 \mathrm{ppm}$. On the other hand, the interaction between compost, active yeast and vitamins treatments was not significant for protein content (\%). We conclude that supply guar plants with compost at 3.75 ton/fed., and spraying plants with either active yeast at $5 \mathrm{~g} / \mathrm{l}$. or ascorbic acid (vit. C) at $50 \mathrm{ppm}$ to improve the values of some chemical constituents under investigation condition.
\end{abstract}

Keywords: Guar, Compost, Vitamin C, Active yeast, Chemical constituents

\section{INTRODUCTION}

Guar, Cyamopsis tetragonoloba, L. Taub. (cluster bean vegetable), an annual summer adapted well to arid and semi-arid climatic zones 65 [1]. It is also known as saline and drought resistant plant; it belongs to Family Fabaceae [2]. Guar is known and grown in Egypt as forage crop. Primarily, its green manure and seed production have considered as animal nutritive substances as its protein content $16 \%$. Recently, the interest has expanded to use a source of glactomannan gum. The endosperm containts guaran gum (20-30 \%), a polymer of glactose (36\%) and manose (64\%), known as glactomannan [3]. The gum is used in food industry [4], it can also be used for treating diabetes mellitus, hyperglycemia, glycosuria and hyperlipopropteinemia and the seeds are used as a laxative [5]. Recently, the interest has extended to be use as a source of galactomannan gum.

Organic manures are important for medicinal plants to produce the best product in both quantity and quality and it is also very safe for human health and environment [6]. Composts are ecofriendly organic supplements which are not harmful for even soil microbiota [7]. Recently, great attention has been focused on the possibility of using natural substances, i.e. vitamins ( $\mathrm{E}$ or $\mathrm{B}_{1}$ or $\mathrm{C}$ ) and yeast in order to improve plant growth, flowering, fruit setting and yield.

Alpha-tocopherols (vitamin E), are secondary metabolites which protects plants from various abiotic stresses [8, 9]. Thiamine (vitamin $B_{1}$ ) is an essential for the synthesis of succinyl-Co-A and glycerin and for the reaction of them to form aminolevulinic acid [10], the main intermediate for formation of protoprophyrin in the precursor of chlorophyll [11] and a factor in the decarboxylation of pyruvate. In addition, various physiological processes depend more or less on the availability of vitamin B [12]. Moreover, [13] obtained pronounced increments in lemongrass yield, vegetative growth, as well as, essential oil percentage due to applying thiamine.

Ascorbic acid (vitamin C) an important antioxidant in plants which helps the plants to overcome stressful conditions [14]. In addition, yeast extract is a source of many natural plant growth substances (cytokinins), large

Received 21 November 2017; Accepted 30 December 2017

*Corresponding Author

Abeer M. Shehata

Medicinal and Aromatic Plants Researches Department, Horticulture Research Institute, Agricultural Research Center, Egypt

Email: abeershehata2006@yahoo.com

(T) This article is open access and licensed under the terms of the Creative Commons Attribution License (http://creativecommons.org/licenses/by/4.o/) which permits unrestricted, use, distribution and reproduction in any medium, or format for any purpose, even commercially provided the work is properly cited. Attribution - You must give appropriate credit, provide a link to the license, and indicate if changes were made. 
amount of vitamin $\mathrm{B}$ and most of nutritional elements ( $\mathrm{P}$, $\mathrm{K}, \mathrm{S}, \mathrm{Na}$, Ca and $\mathrm{Mg}$ ), as well as, organic compound (high protein, carbohydrates, nucleic acids and lipids) [15].

Therefore, the present study was carried out to investigate the effect of organic manure (compost) and some natural substances (vitamin $\mathrm{E}, \mathrm{B}_{1}$ and $\mathrm{C}$, as well as, active yeast) treatments on some chemical constituents of Cyamopsis tetragonoloba, L. plant.

\section{MATERIALS AND METHODS}

The present work was concluded at the Floriculture Nursery, Faculty of Agriculture, Minia University during the two successive seasons of 2010 and 2011 to study the effect of compost in combination with active yeast and some vitamins on growth, yield and guaran content of guar gum (Cyamopsis tetragonoloba, Taub.). Table (1) shows the physical and chemical properties of the used soil in both seasons.

The layout of this experiment during both seasons was split plot design with three replicates. The main-plots included four compost treatments $(0,1.25,2.50$ and 3.75 ton/feddan.), while the sub-plots were devoted to nine treatments; control, a-tocopherol (vit. E.) at 10 and 20 ppm, thiamine (vit. $\mathrm{B}_{1}$ ) at 25 and $50 \mathrm{ppm}$, ascorbic acid (vit. C) at 50 and $100 \mathrm{ppm}$ and active yeast (AY) at 2.5 and $5 \mathrm{~g} / \mathrm{l}$. Compost were added during soil preparation for cultivation in both seasons. The physical and chemical properties of the used compost are shown in table (2).
The plants were harvested of the fourth week of September in both seasons and the following data were recorded during the two seasons.

\section{Guaran determinations}

Concerning guaran determination of oven-dried seeds were determined according to [16].

\section{Pigments determination}

The contents of photosynthetic pigments namely; chlorophyll $\mathrm{a}, \mathrm{b}$ and carotenoids (mg/g f. w.) of fresh leaves were determined according to [17] using the spectrophotometer at wave length of 656,665 and $452.5 \mu \mathrm{m}$, respectively.

\section{Total carbohydrates percentage}

Total carbohydrates including poly-saccharides in dry leaves of each experiment unit were colorimetrically determined with the anthrone sulphuric acid method [18]

\section{$\mathbf{N}, \mathbf{P}$ and $K$ percentages}

A sample weight of $0.2 \mathrm{~g}$ fine powder of the dry herb was digested using a mixture of hydrogen peroxide $\left(\mathrm{H}_{2} \mathrm{O}_{2}\right)$ and concentrated sulphuric acid $\left(\mathrm{H}_{2} \mathrm{SO}_{4}\right)$ (4:10). The clear digestion was quantitively $100 \mathrm{ml}$ volumetric flask. In this solution, the following elements were determined:

Nitrogen (\%) was determined according to the modified Microkjeldahle method as described by [19]. Phosphorus (\%) was determined colorimetrically by the spectrophotometer at wavelength of $650 \mu \mathrm{m}$ according to the method of [20]. Potassium (\%) was determined using flame-photometry method according to [21].

Table 1: The physical and chemical properties of the used soil

\begin{tabular}{|c|c|c|c|c|}
\hline Soil character & Values & \multicolumn{2}{|c|}{ Soil character } & Values \\
\hline Sand \% & 28.30 & \multicolumn{2}{|c|}{ Available P \% } & 15.12 \\
\hline Silt \% & 30.70 & \multicolumn{2}{|c|}{ Exchangeable $\mathrm{K}^{+} \mathrm{mg} / 100 \mathrm{~g}$ soil } & 2.11 \\
\hline Clay \% & 41.0 & \multicolumn{2}{|c|}{ Exch. $\mathrm{Ca}^{++} \mathrm{mg} / 100 \mathrm{~g}$ soil } & 31.74 \\
\hline Soil type & Clay loam & \multicolumn{2}{|c|}{ Exch. $\mathrm{Na}^{+} \mathrm{mg} / 100 \mathrm{~g}$ soil } & 2.41 \\
\hline Organic matter \% & 1.62 & & & \\
\hline $\mathrm{CaCO}_{3} \%$ & 2.09 & & $\mathrm{Fe}$ & 8.54 \\
\hline pH 1:2.5 & 7.83 & DTPA & $\mathrm{Cu}$ & 2.06 \\
\hline E. C. $\mathrm{m} \mathrm{mhose} / \mathrm{cm}$ & 1.04 & Ext.ppm & $\mathrm{Zn}$ & 2.75 \\
\hline Total N \% & 0.08 & & $\mathrm{Mn}$ & 8.26 \\
\hline
\end{tabular}

The experimental unit (plot) was $2 \times 2.4$ meters and contained 3 rows, $50 \mathrm{~cm}$ apart and seeds were sown in hills, $30 \mathrm{~cm}$ apart, on $30^{\text {th }}$ March in both seasons. Seedlings were thinned to one plant/hill, after one month from sowing.

Table 2: The physical and chemical properties of the used compost

\begin{tabular}{llll}
\hline Properties & Value & Properties & Value \\
\hline Dry weight of $1 \mathrm{~m}^{3}$ & $450 \mathrm{~kg}$ & NaCl \% & $1.1-1.75$ \\
Fresh weight of $1 \mathrm{~m}^{3}$ & $650-700 \mathrm{~kg}$ & Total P \% & $0.5-0.75$ \\
Moisture (\%) & $25-30$ & Total K \% & $0.8-1.0$ \\
pH (1:10) & $7.5-8$ & Fe ppm & $150-200$ \\
E. C. $(\mathrm{m}$ mhose/cm) & $2-4$ & Mn ppm & 25.56 \\
Total N \% & $1-1.4$ & $\mathrm{Cu} \mathrm{ppm}$ & $75-150$ \\
Org. matter \% & $32-34$ & Zn ppm & $150-225$ \\
Org. carbon \% & $18.5-19.7$ & & \\
C/N ratio & $18.5-14.1$ & & \\
\hline
\end{tabular}

Each of vitamins and suspension of yeast were applied by hand sprayer 3 times. The first one was added after $5 \mathrm{w}$ from planting date and two weeks thereafter. The plants were sprayed till run off. All agricultural practices were performed as usual, in the region for the production of guar plants. 


\section{Protein percentage}

Protein percentage was estimated by multiplying nitrogen percent by 6.25 . This was based on the assumption that the protein contains $16 \%$ nitrogen, according to the method of [22].

\section{Statistical analysis}

The data of the two seasons were subjected to the statistical analysis of variance using [23]. L. SD test at 0.05 was used to compare the means of treatments.

\section{RESULTS AND DISSECTION}

\section{Guaran percentage in the seeds}

Regarding compost levels, data presented in table (3) revealed that guaran \% in the dry seeds of Cyamopsis tetragonoloba, L. was significantly increased as a result of fertilizing plants with all used levels of compost treatments over the control in both seasons. The highest guaran \% was obtained due to the treatment of compost at high level (3.75 ton/fed.) followed by the treatment of low level (1.25 ton/fed.) with significant differences detected among themselves in both growing seasons.

The enhancement of guaran \% obtained in the present work due to using organic manure was also reported by [24] and [25] on guar plants.

Table (3) indicated that all examined eight treatments of vitamins and active yeast significantly increased guaran percentage in the dry seeds of Cyamopsis tetragonoloba,
L., except for the treatment of vit. $\mathrm{C}$ at $100 \mathrm{ppm}$ in comparison with the control in the two growing seasons. The low concentrations of the three used vitamins treatments proved to be more effective than their high concentrations in this respect. However, active yeast at 5 $\mathrm{g} / \mathrm{l}$. was more effective than $2.5 \mathrm{~g} / \mathrm{l}$. in improving guaran $\%$. The treatments of active yeast ( $5 \mathrm{~g} / \mathrm{l}$.) followed by vit. $\mathrm{C}$ (50 ppm) then $\mathrm{B} 1(25 \mathrm{ppm})$ resulted the highest guaran $\%$ with significant differences detected among themselves in both seasons. The least guaran \% resulted from control treatment. The other treatments gave intermediate values. In this respect, [24 ]on guar plants found that the highest values of guaran \% were obtained due to the application of farmyard manure accompanied by Rhizobium and yeast. The interaction between the two main factors $(\mathrm{A} \times \mathrm{B})$ was significant for guaran $\%$ in the second season as illustrated in table (3). The superior interaction treatment over all was compost at high level (3.75 ton/fed.) in combination with active yeast at $5 \mathrm{~g} / \mathrm{l}$.

\section{Photosynthetic pigments}

The contents of the three studied photosynthetic pigments (chlorophyll a, b and carotenoids) were significantly enhanced by compost levels $(1.25,2.50$ and 3.75 ton/fed.) in the two growing seasons as shown in Tables $(4,5$ and 6). However, the maximum values were obtained by high level of compost (3.75 ton/fed.). In regard to the enhancement influence of organic fertilization, the previous results were in agreement with those of [26] on coriander; [27] on Phaseolus vulgaris and [28] on spider plant.

Table 3: Effect of compost, some vitamins and active yeast treatments on guaran \% of Cyamopsis tetragonoloba seeds during 2010 and 2011 seasons

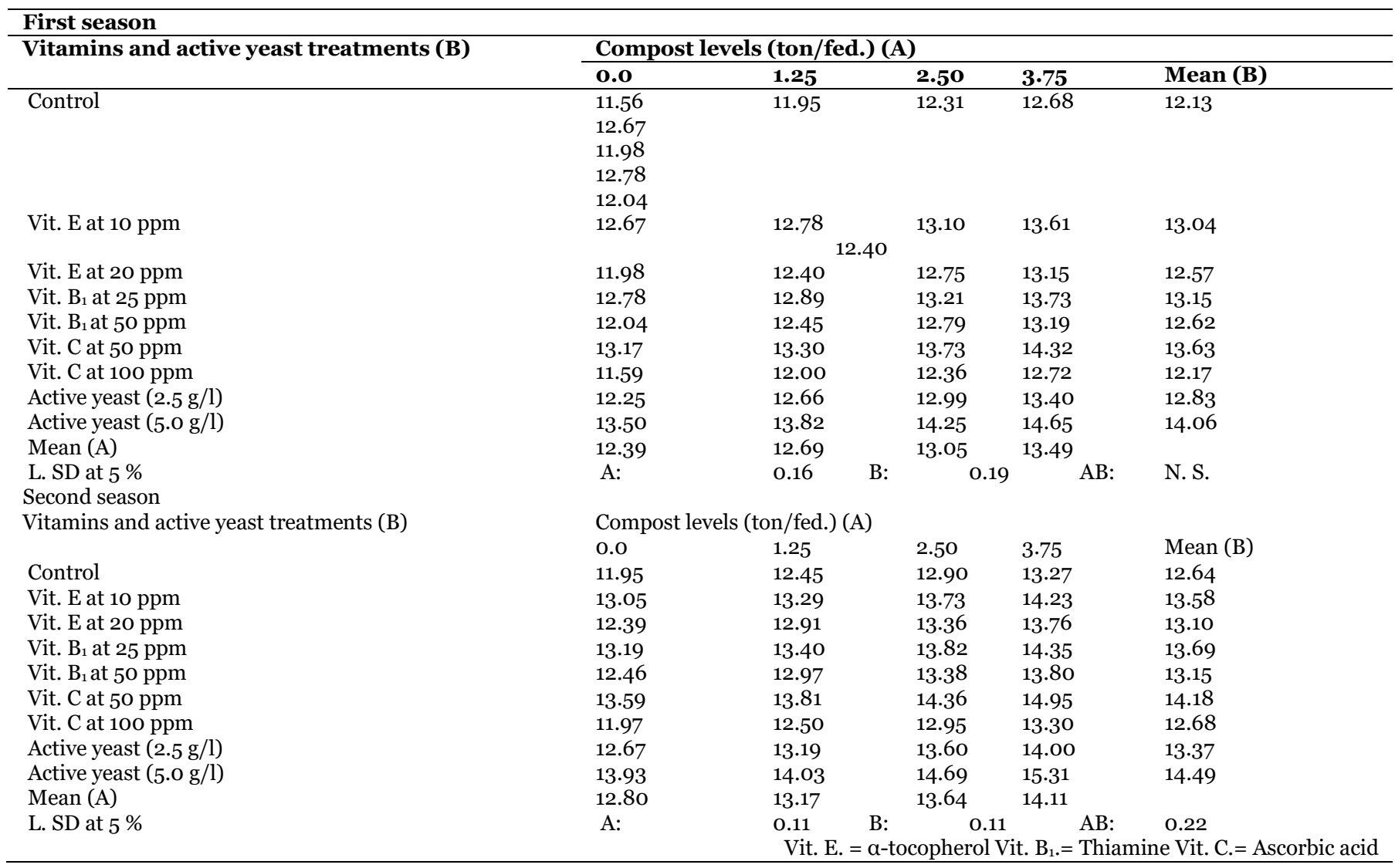


Table 4: Effect of compost, some vitamins and active yeast treatments on chlorophyll a content (mg/g f. w.) of Cyamopsis tetragonoloba during 2010 and 2011 seasons

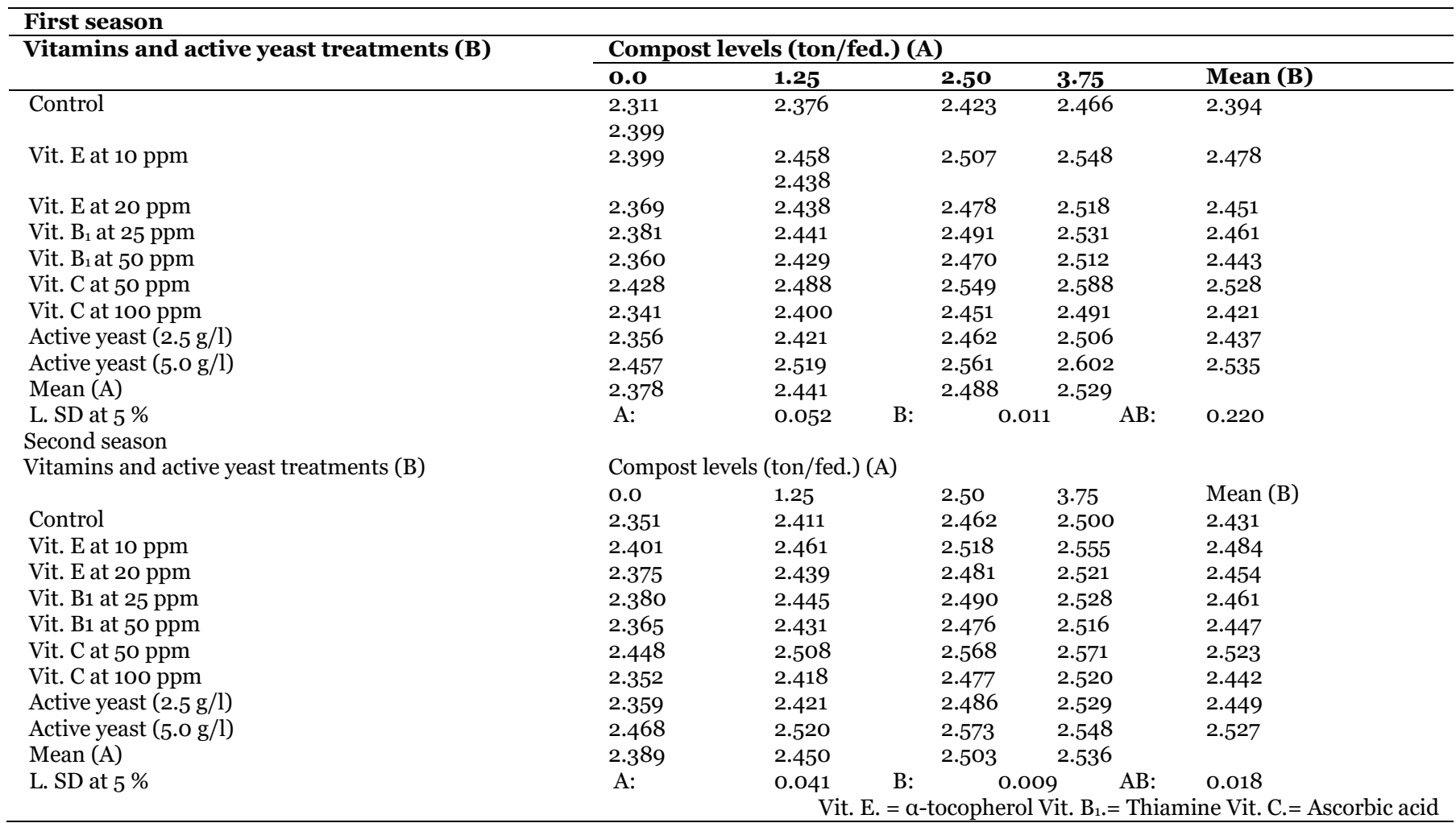

Table 5: Effect of compost, some vitamins and active yeast treatments on chlorophyll b content (mg/g f. w.) of Cyamopsis tetragonoloba during 2010 and 2011 seasons

\begin{tabular}{|c|c|c|c|c|c|c|}
\hline \multicolumn{7}{|l|}{ First season } \\
\hline \multirow[t]{2}{*}{ Vitamins and active yeast treatments (B) } & \multicolumn{6}{|c|}{ Compost levels (ton/fed.) (A) } \\
\hline & $\mathbf{0 . 0}$ & 1.25 & 2.50 & & $3 \cdot 75$ & Mean (B) \\
\hline Control & $\begin{array}{l}0.771 \\
0.801\end{array}$ & 0.794 & 0.807 & & 0.822 & 0.799 \\
\hline Vit. E at $10 \mathrm{ppm}$ & 0.801 & $\begin{array}{l}0.820 \\
0.815\end{array}$ & 0.853 & & 0.967 & 0.860 \\
\hline Vit. E at $20 \mathrm{ppm}$ & 0.790 & 0.815 & 0.841 & & 0.851 & 0.824 \\
\hline Vit. B1 at $25 \mathrm{ppm}$ & 0.795 & 0.813 & 0.846 & & 0.859 & 0.828 \\
\hline Vit. B1 at $50 \mathrm{ppm}$ & 0.787 & 0.812 & 0.835 & & 0.841 & 0.819 \\
\hline Vit. C at $50 \mathrm{ppm}$ & 0.809 & 0.829 & 0.856 & & 0.980 & 0.869 \\
\hline Vit. $\mathrm{C}$ at $100 \mathrm{ppm}$ & 0.781 & 0.800 & 0.817 & & 0.830 & 0.807 \\
\hline Active yeast $(2.5 \mathrm{~g} / \mathrm{l})$ & 0.785 & 0.807 & 0.821 & & 0.836 & 0.812 \\
\hline Active yeast (5.0 g/l) & 0.819 & 0.839 & 0.866 & & 0.985 & 0.877 \\
\hline Mean (A) & 0.793 & 0.814 & 0.838 & & 0.886 & \\
\hline L. SD at $5 \%$ & A: & 0.018 & B: & 0.007 & $\mathrm{AB}:$ & 0.014 \\
\hline \multicolumn{7}{|l|}{ Second season } \\
\hline \multirow[t]{2}{*}{ Vitamins and active yeast treatments (B) } & \multicolumn{6}{|c|}{ Compost levels (ton/fed.) (A) } \\
\hline & 0.0 & 1.25 & 2.50 & & $3 \cdot 75$ & Mean (B) \\
\hline Control & 0.783 & 0.805 & 0.820 & & 0.831 & 0.810 \\
\hline Vit. E at $10 \mathrm{ppm}$ & 0.808 & 0.828 & 0.860 & & 0.973 & 0.867 \\
\hline Vit. E at $20 \mathrm{ppm}$ & 0.791 & 0.813 & 0.833 & & 0.855 & 0.823 \\
\hline Vit. B1 at $25 \mathrm{ppm}$ & 0.799 & 0.816 & 0.838 & & 0.860 & 0.828 \\
\hline Vit. B1 at 50 ppm & 0.791 & 0.811 & 0.833 & & 0.850 & 0.821 \\
\hline Vit. C at $50 \mathrm{ppm}$ & 0.809 & 0.836 & 0.871 & & 0.988 & 0.878 \\
\hline Vit. C at $100 \mathrm{ppm}$ & 0.784 & 0.808 & 0.825 & & 0.840 & 0.814 \\
\hline Active yeast $(2.5 \mathrm{~g} / \mathrm{l})$ & 0.788 & 0.809 & 0.829 & & 0.843 & 0.817 \\
\hline Active yeast ( $5.0 \mathrm{~g} / \mathrm{l})$ & 0.821 & 0.843 & 0.868 & & 0.991 & 0.881 \\
\hline Mean (A) & 0.797 & 0.819 & 0.842 & & 0.892 & \\
\hline L. SD at $5 \%$ & A: & 0.015 & $\mathrm{~B}:$ & 0.003 & $\mathrm{AB}:$ & 0.006 \\
\hline & & Vit. E. & ocophe & l Vit. B & niamine & $=$ Ascorbic \\
\hline
\end{tabular}


Table 6: Effect of compost, some vitamins and active yeast treatments on carotenoids content ( $\mathrm{mg} / \mathrm{g}$ f. $\mathrm{w}$.$) of$ Cyamopsis tetragonoloba during 2010 and 2011 seasons

\begin{tabular}{|c|c|c|c|c|c|c|}
\hline \multicolumn{7}{|l|}{ First season } \\
\hline \multirow[t]{2}{*}{ Vitamins and active yeast treatments (B) } & \multicolumn{6}{|c|}{ Compost levels (ton/fed.) (A) } \\
\hline & $\mathbf{0 . 0}$ & 1.25 & 2.50 & & $3 \cdot 75$ & Mean (B) \\
\hline Control & 0.793 & 0.811 & 0.819 & & 0.834 & 0.814 \\
\hline Vit. E at $10 \mathrm{ppm}$ & 0.822 & $\begin{array}{l}0.850 \\
0.851\end{array}$ & 0.867 & & 0.888 & 0.857 \\
\hline Vit. E at $20 \mathrm{ppm}$ & 0.809 & 0.839 & 0.851 & & 0.876 & 0.844 \\
\hline Vit. B1 at $25 \mathrm{ppm}$ & 0.815 & 0.843 & 0.861 & & 0.881 & 0.850 \\
\hline Vit. B1 at $50 \mathrm{ppm}$ & 0.805 & 0.831 & 0.841 & & 0.866 & 0.836 \\
\hline Vit. C at $50 \mathrm{ppm}$ & 0.829 & 0.859 & 0.880 & & 0.899 & 0.867 \\
\hline Vit. C at $100 \mathrm{ppm}$ & 0.796 & 0.818 & 0.828 & & 0.846 & 0.822 \\
\hline Active yeast $(2.5 \mathrm{~g} / \mathrm{l})$ & 0.799 & 0.826 & 0.836 & & 0.858 & 0.830 \\
\hline Active yeast $(5.0 \mathrm{~g} / \mathrm{l})$ & 0.838 & 0.866 & 0.910 & & 0.930 & 0.886 \\
\hline Mean (A) & 0.812 & 0.838 & 0.855 & & 0.875 & \\
\hline L. SD at $5 \%$ & A: & 0.019 & B: & 0.006 & $\mathrm{AB}:$ & 0.012 \\
\hline \multicolumn{7}{|l|}{ Second season } \\
\hline \multirow[t]{2}{*}{ Vitamins and active yeast treatments (B) } & \multicolumn{6}{|c|}{ Compost levels (ton/fed.) (A) } \\
\hline & 0.0 & 1.25 & 2.50 & & 3.75 & Mean (B) \\
\hline Control & 0.795 & 0.818 & 0.836 & & 0.846 & 0.824 \\
\hline Vit. E at $10 \mathrm{ppm}$ & 0.829 & 0.860 & 0.875 & & 0.896 & 0.865 \\
\hline Vit. $\mathrm{E}$ at $20 \mathrm{ppm}$ & 0.811 & 0.832 & 0.852 & & 0.876 & 0.843 \\
\hline Vit. B1 at $25 \mathrm{ppm}$ & 0.817 & 0.839 & 0.859 & & 0.886 & 0.850 \\
\hline Vit. B1 at $50 \mathrm{ppm}$ & 0.810 & 0.832 & 0.846 & & 0.869 & 0.839 \\
\hline Vit. C at $50 \mathrm{ppm}$ & 0.831 & 0.863 & 0.899 & & 0.906 & 0.875 \\
\hline Vit. C at $100 \mathrm{ppm}$ & 0.796 & 0.825 & 0.838 & & 0.853 & 0.828 \\
\hline Active yeast $(2.5 \mathrm{~g} / \mathrm{l})$ & 0.801 & 0.831 & 0.846 & & 0.862 & 0.835 \\
\hline Active yeast $(5.0 \mathrm{~g} / \mathrm{l})$ & 0.842 & 0.869 & 0.912 & & 0.939 & 0.891 \\
\hline Mean (A) & 0.814 & 0.841 & 0.863 & & 0.881 & \\
\hline L. SD at $5 \%$ & A: & 0.018 & B: & 0.011 & $\mathrm{AB}:$ & 0.022 \\
\hline
\end{tabular}

Table 7: Effect of compost, some vitamins and active yeast treatments on total carbohydrates (\%) of Cyamopsis tetragonoloba during 2010 and 2011 seasons

\begin{tabular}{|c|c|c|c|c|c|c|}
\hline \multicolumn{7}{|l|}{ First season } \\
\hline \multirow[t]{2}{*}{ Vitamins and active yeast treatments (B) } & \multicolumn{6}{|c|}{ Compost levels (ton/fed.) (A) } \\
\hline & O.o & 1.25 & 2.50 & & $3 \cdot 75$ & Mean (B) \\
\hline Control & 22.2 & $25 \cdot 3$ & 27.1 & & 29.5 & 26.0 \\
\hline Vit. E at $10 \mathrm{ppm}$ & 23.5 & $\begin{array}{l}28.2 \\
2.80\end{array}$ & 29.5 & & 31.8 & 28.3 \\
\hline Vit. E at $20 \mathrm{ppm}$ & $23 \cdot 3$ & 28.0 & 29.1 & & 31.3 & 27.9 \\
\hline Vit. B1 at $25 \mathrm{ppm}$ & 23.4 & 28.1 & 29.3 & & 31.4 & 28.0 \\
\hline Vit. B1 at $50 \mathrm{ppm}$ & 23.2 & 27.9 & 29.1 & & 31.2 & 27.9 \\
\hline Vit. C at $50 \mathrm{ppm}$ & 23.8 & 28.5 & 29.9 & & 32.1 & 28.6 \\
\hline Vit. C at 100 ppm & 23.1 & 26.4 & 28.3 & & 30.1 & 27.0 \\
\hline Active yeast $(2.5 \mathrm{~g} / \mathrm{l})$ & 23.7 & 27.1 & 29.1 & & 31.1 & 27.8 \\
\hline Active yeast $(5.0 \mathrm{~g} / \mathrm{l})$ & 23.6 & 28.3 & 29.6 & & 31.9 & 28.4 \\
\hline Mean (A) & $23 \cdot 3$ & $25 \cdot 3$ & 29.0 & & 31.2 & \\
\hline L. SD at $5 \%$ & A: & 0.18 & B: & 0.4 & $\mathrm{AB}:$ & 0.8 \\
\hline \multicolumn{7}{|l|}{ Second season } \\
\hline \multirow[t]{2}{*}{ Vitamins and active yeast treatments (B) } & \multicolumn{6}{|c|}{ Compost levels (ton/fed.) (A) } \\
\hline & 0.0 & 1.25 & 2.50 & & 3.75 & Mean (B) \\
\hline Control & 23.5 & 26.7 & 27.9 & & 29.4 & 26.9 \\
\hline Vit. E at $10 \mathrm{ppm}$ & 23.6 & 28.6 & 29.4 & & 31.8 & 28.4 \\
\hline Vit. E at $20 \mathrm{ppm}$ & 23.4 & 28.1 & 29.2 & & 31.6 & 28.1 \\
\hline Vit. B1 at $25 \mathrm{ppm}$ & 23.4 & 28.2 & 29.2 & & 31.5 & 28.0 \\
\hline Vit. B1 at $50 \mathrm{ppm}$ & 23.3 & 28.0 & 29.1 & & 31.5 & 28.0 \\
\hline Vit. C at $50 \mathrm{ppm}$ & 23.7 & 29.5 & 31.1 & & 31.3 & 28.9 \\
\hline Vit. C at 100 ppm & 23.2 & 26.5 & 28.3 & & 30.3 & 27.2 \\
\hline Active yeast $(2.5 \mathrm{~g} / \mathrm{l})$ & 23.9 & 27.2 & 29.2 & & 31.2 & 27.9 \\
\hline Active yeast $(5.0 \mathrm{~g} / \mathrm{l})$ & 23.6 & 28.7 & 29.6 & & 31.9 & 28.5 \\
\hline Mean (A) & 23.5 & 27.9 & 29.4 & & 31.3 & \\
\hline \multirow[t]{2}{*}{ L. SD at $5 \%$} & A: & 2.5 & B: & 0.5 & $\mathrm{AB}:$ & 1.0 \\
\hline & \multicolumn{6}{|c|}{ Vit. E. = $\alpha$-tocopherol Vit. B1.= Thiamine Vit. C.= Ascorbic acid } \\
\hline
\end{tabular}

Data presented in Tables (4, 5 and 6) showed that all spraying treatments significantly increased the chlorophyll a, b and carotenoids contents (mg/g. f. w.) over the check treatment. The highest contents of the previous characters resulted from the plants which received active yeast at $5 \mathrm{~g} / \mathrm{l}$. followed by vit. $\mathrm{C}$ at $50 \mathrm{ppm}$ in both experimental seasons. 
The interaction between compost and spraying treatments was significant in both seasons for the three photosynthetic pigments. The highest contents of chlorophyll $\mathrm{a}, \mathrm{b}$ and carotenoids in the fresh leaves of guar plants was obtained from the interaction treatments of 3.75 ton/fed., compost in combination with active yeast at $5 \mathrm{~g} / \mathrm{l}$. and vit. $\mathrm{C}$ at $50 \mathrm{ppm}$. Similar results were obtained by [29] on coriander; [30] on black cumin and anise and [31] on sage who found that the interaction between farmyard manure with yeast significantly increased chlorophyll a, b and carotenoids. Also, [32] on caraway; [33] on fennel and [34] on black cumin recorded that the highest contents of chl. a, b and carotenoids were obtained from the treatment of compost in combination with ascorbic acid.

\section{Total carbohydrates percentage}

Data presented in table (7) indicated that supplying guar plants with compost at $1.25,2.50$ and 3.75 ton/fed., resulted in a significant increase in the total carbohydrate percentage in the dry seeds of plant compared to control plants. The increase of carbohydrate \% was gradually increased with the gradual increase of compost level in the two experimental seasons. The beneficial effect of organic fertilization on carbohydrate was obtained by [35] on Sideritis monata; [36] on oregano plants; [37] on Lawsonia alba; [38] on Vicia faba; [39] on kidney bean and [40] on sugar beet plant.
Concerning the influence of spraying treatments [(vit. C, E and $\left.\mathrm{B}_{1}\right)$ ] and active yeast, each at two concentrations on carbohydrate \%, data presented in table (7) showed that all used eight treatments increased the percentage of carbohydrate compared to untreated plants in both seasons. Using the treatments of vit. $\mathrm{C}$ at $50 \mathrm{ppm}$ followed by $5 \mathrm{~g} / \mathrm{l}$. active yeast, then vit. $\mathrm{E}$ at $10 \mathrm{ppm}$ gave the highest values in this concern without significant differences detected among themselves.

Regarding ascorbic acid these results agree with those of [41] on Vicia faba. However, [39 ]on kidney bean; [42] on Vicia faba and [40] on sugar beet, concluded that active yeast increased total carbohydrates in plants. Moreover, [43] on Syngonium podophyllum found that total carbohydrates content was significantly increased when plants were treated with thiamine, ascorbic acid and kinetin.

Regarding interaction between the two main factors $(\mathrm{A} \times \mathrm{B})$ it significantly increased carbohydrate \% in both two seasons as shown in table (7). The highest values were obtained by the interaction treatments of compost $(3.75$ ton/fed.) in combination with vit. C (50 ppm), active yeast (5 g/l.) or vit. E (10 ppm) during the first season. Moreover, the interaction between high level of compost (3.75 ton/fed.) in combination with any tested spraying treatment, except for vit. $\mathrm{C}$ at $100 \mathrm{ppm}$ gave the best interaction treatments.

Table 8: Effect of compost, some vitamins and active yeast treatments on $\mathbf{N}(\%)$ of Cyamopsis tetragonoloba during 2010 and 2011 seasons

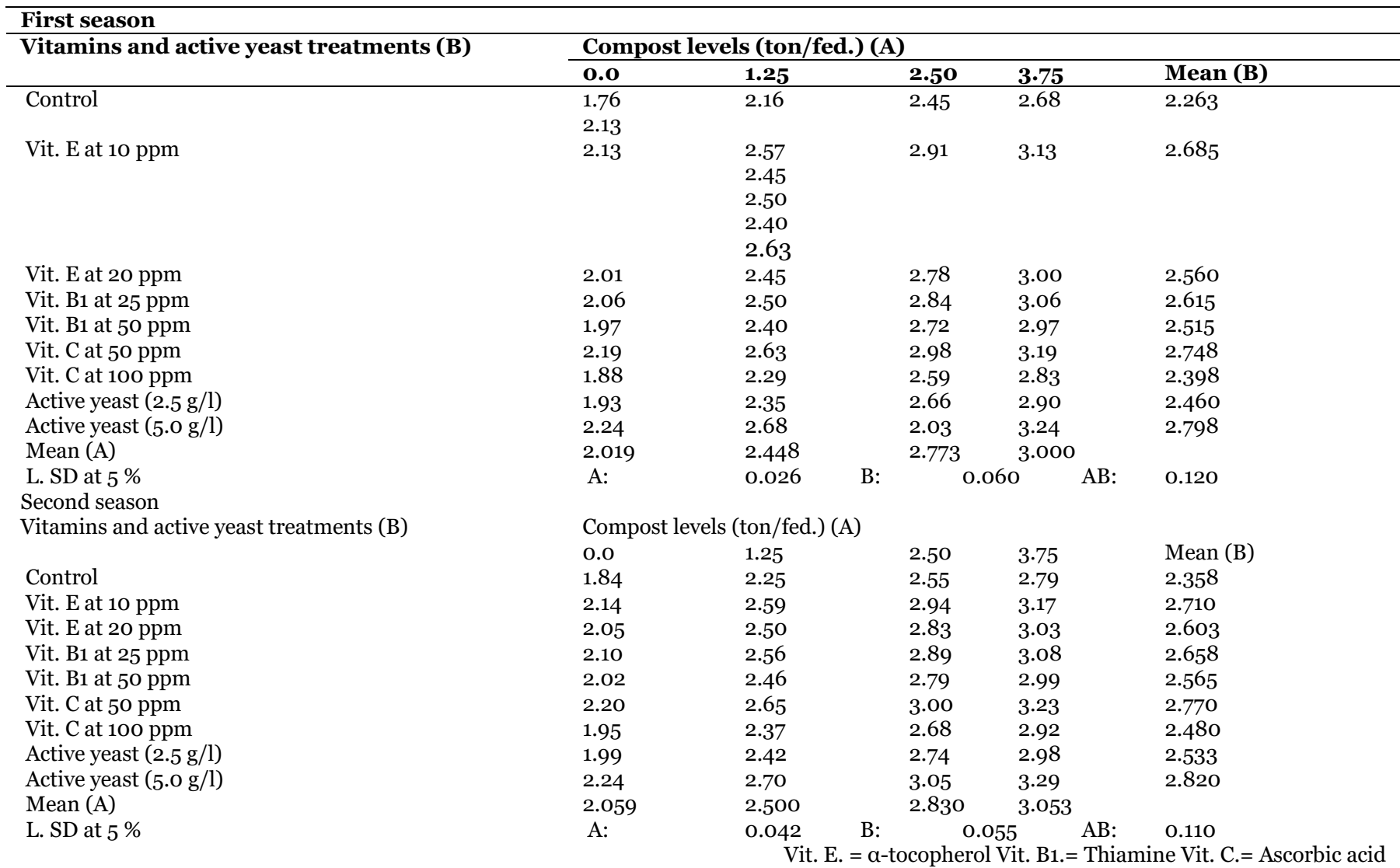


Hortic. Biotechnol. Res. 2017, 3: 26-36

http://updatepublishing.com/journal/index.php/hbr/

Table 9: Effect of compost, some vitamins and active yeast treatments on $P$ (\%) of Cyamopsis tetragonoloba during 2010 and 2011 seasons

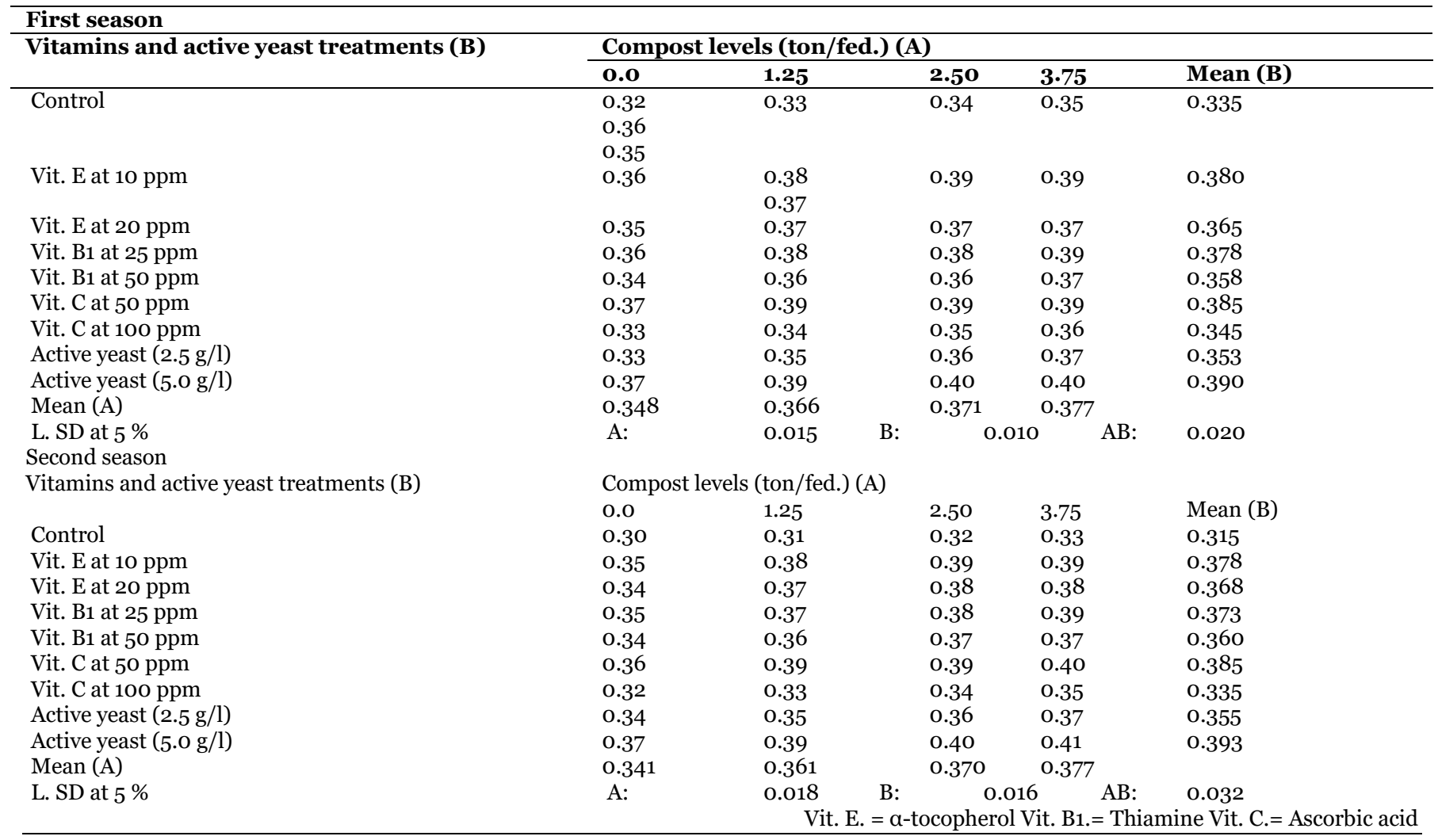

Table 10: Effect of compost, some vitamins and active yeast treatments on $\mathrm{K}(\%)$ of Cyamopsis tetragonoloba during 2010 and 2011 seasons

\begin{tabular}{|c|c|c|c|c|c|c|}
\hline \multicolumn{7}{|l|}{ First season } \\
\hline \multirow[t]{2}{*}{ Vitamins and active yeast treatments (B) } & \multicolumn{6}{|c|}{ Compost levels (ton/fed.) (A) } \\
\hline & $\mathbf{0 . 0}$ & 1.25 & 2.50 & & 3.75 & Mean (B) \\
\hline \multirow[t]{2}{*}{ Control } & 1.30 & 1.33 & 1.36 & & 1.40 & 1.348 \\
\hline & 1.35 & & & & & \\
\hline \multirow[t]{5}{*}{ Vit. E at $10 \mathrm{ppm}$} & 1.35 & 1.40 & 1.41 & & 1.48 & 1.400 \\
\hline & & 1.39 & & & & \\
\hline & & 1.39 & & & & \\
\hline & & 1.38 & & & & \\
\hline & & 1.40 & & & & \\
\hline Vit. E at $20 \mathrm{ppm}$ & 1.34 & 1.39 & 1.39 & & 1.46 & 1.395 \\
\hline Vit. $\mathrm{B} 1$ at $25 \mathrm{ppm}$ & 1.35 & 1.39 & 1.40 & & 1.47 & 1.403 \\
\hline Vit. B1 at $50 \mathrm{ppm}$ & 1.34 & 1.38 & 1.39 & & 1.45 & 1.390 \\
\hline Vit. C at $50 \mathrm{ppm}$ & 1.36 & 1.40 & 1.42 & & 1.48 & 1.415 \\
\hline Vit. C at $100 \mathrm{ppm}$ & 1.33 & 1.36 & 1.38 & & 1.43 & 1.375 \\
\hline Active yeast $(2.5 \mathrm{~g} / \mathrm{l})$ & 1.33 & 1.37 & 1.39 & & 1.44 & 1.383 \\
\hline Active yeast $(5.0 \mathrm{~g} / \mathrm{l})$ & 1.36 & 1.41 & 1.43 & & 1.49 & 1.423 \\
\hline Mean (A) & 1.340 & 1.381 & 1.397 & & 1.456 & \\
\hline L. SD at $5 \%$ & A: & 0.022 & B: & 0.024 & AB: & N.S. \\
\hline \multicolumn{7}{|l|}{ Second season } \\
\hline \multirow[t]{2}{*}{ Vitamins and active yeast treatments (B) } & \multicolumn{6}{|c|}{ Compost levels (ton/fed.) (A) } \\
\hline & 0.0 & 1.25 & 2.50 & & $3 \cdot 75$ & Mean (B) \\
\hline Control & 1.28 & 1.30 & 1.34 & & 1.36 & 1.320 \\
\hline Vit. E at $10 \mathrm{ppm}$ & 1.36 & 1.38 & 1.40 & & 1.41 & 1.388 \\
\hline Vit. E at $20 \mathrm{ppm}$ & 1.34 & 1.36 & 1.39 & & 1.41 & 1.375 \\
\hline Vit. B1 at $25 \mathrm{ppm}$ & 1.35 & 1.37 & 1.39 & & 1.42 & 1.383 \\
\hline Vit. B1 at $50 \mathrm{ppm}$ & 1.33 & 1.35 & 1.38 & & 1.40 & 1.365 \\
\hline Vit. C at 50 ppm & 1.36 & 1.39 & 1.41 & & 1.42 & 1.395 \\
\hline Vit. C at 100 ppm & 1.31 & 1.33 & 1.37 & & 1.39 & 1.350 \\
\hline Active yeast $(2.5 \mathrm{~g} / \mathrm{l})$ & 1.32 & 1.34 & 1.37 & & 1.40 & 1.358 \\
\hline Active yeast $(5.0 \mathrm{~g} / \mathrm{l})$ & 1.37 & 1.39 & 1.42 & & 1.43 & 1.403 \\
\hline Mean (A) & 1.336 & 1.357 & 1.386 & & 1.404 & \\
\hline \multirow[t]{2}{*}{ L. SD at $5 \%$} & A: & 0.022 & B: & 0.017 & $\mathrm{AB}:$ & N.S. \\
\hline & & \multicolumn{5}{|c|}{ Vit. E. $=\alpha$-tocopherol Vit. B1. $=$ Thiamine Vit. C. $=$ Ascorbic acid } \\
\hline
\end{tabular}




\section{Nitrogen, phosphorus and potassium \%}

Data presented in Tables (8, 9 and 10) showed that the increase in $\mathrm{N}, \mathrm{P}$ and $\mathrm{K} \%$ in the dry leaves of guar plants was parallel to the increase in compost level. The high level of compost (3.75 ton/fed.) followed by medium level (1.25 ton/fed.) significantly increased N, P and K \% in both seasons in comparison with those of control treatment.

The promotive effect of organic manure was found by many authors, namely, [25] on guar; [44] on soybean; [45] on Pisum sativum; [36] on Origanium syriacum; [46] on rosemary; [47] on Eclipta alba; and [48] on roselle plants.

Concerning the treatments of vitamins and active yeast, data presented in Tables (8, 9 and 10) clearly revealed that all used treatments considerably increased $\mathrm{N}, \mathrm{P}$ and $\mathrm{K} \%$ in the dry levels of guar plants in comparison with control plants during both seasons. Active yeast at high level $5 \mathrm{~g} / \mathrm{l}$. followed by ascorbic acid at low concentration (50 ppm) then $\alpha$-tocopherol at low concentration (10 ppm) gave the highest percentages of $\mathrm{N}, \mathrm{P}$ and $\mathrm{K}$ with non-significant differences among themselves in case of $\mathrm{P}$ and $\mathrm{K} \%$. The treatment of vit. $\mathrm{B}_{1}(25 \mathrm{ppm})$ gave the second order in this concern.

Many researchers came to similar results that active yeast augmented NPK \% in the leaves of different plants such as coriander [49]; [26]. Lemongrass [50]. Phaseolus vulgaris [51] and [52]. Vicia faba [38]. The role of vit. C and vit. E in promoting NPK \% was also, reported by [53] on sweet pepper and [54] on eggplant. Regarding the effect of vit. C,
[55] on black cumin; [56] on tomato and [57] on caraway plants concerning the effect of vit. E. Moreover, [58] on tomato; [43] on syngonium and [59] on snap bean found that spraying plants with vit. $\mathrm{B}_{1}$ increased $\mathrm{N}, \mathrm{P}$ and $\mathrm{K}$ total uptake by plant.

The interaction between the two main factors $(\mathrm{A} \times \mathrm{B})$ was significant for $\mathrm{N}$ and $\mathrm{P} \%$ in both seasons as shown in data presented in Tables (8, 9 and 10). The highest $\mathrm{N}$ and $\mathrm{P} \%$ was obtained due to compost (3.75 ton/fed.) in combination with active yeast $(5 \mathrm{~g} / \mathrm{l}$.) followed by vitamin $\mathrm{C}$ and $\mathrm{E}$, each at low concentration.

Similar results were obtained by [6o] on dill; [61] and [62] on faba bean and [63] on pea, concerning the effect of interaction treatment between organic manures and active. However, [64] on caraway and [65] on black cumin concluded that the highest contents of NPK were obtained in combination treatment of compost with ascorbic acid.

\section{Protein (\%)}

Data presented in table (11) showed that the increase in protein \% was due to the increase in compost level. All treatments of compost significantly increased protein \% in the dry seeds of guar in both seasons in comparison with those of control. Moreover the best treatment which produced the highest values of protein content \% was compost at 3.75 ton/fed. The promotive effect of organic manure was found by [24] and [25] on guar; [66] on pigeon pea; [67] on soybean and [48] on roselle plant.

Table 11: Effect of compost, some vitamins and active yeast treatments on protein (\%) of Cyamopsis tetragonoloba seeds during 2010 and 2011 seasons

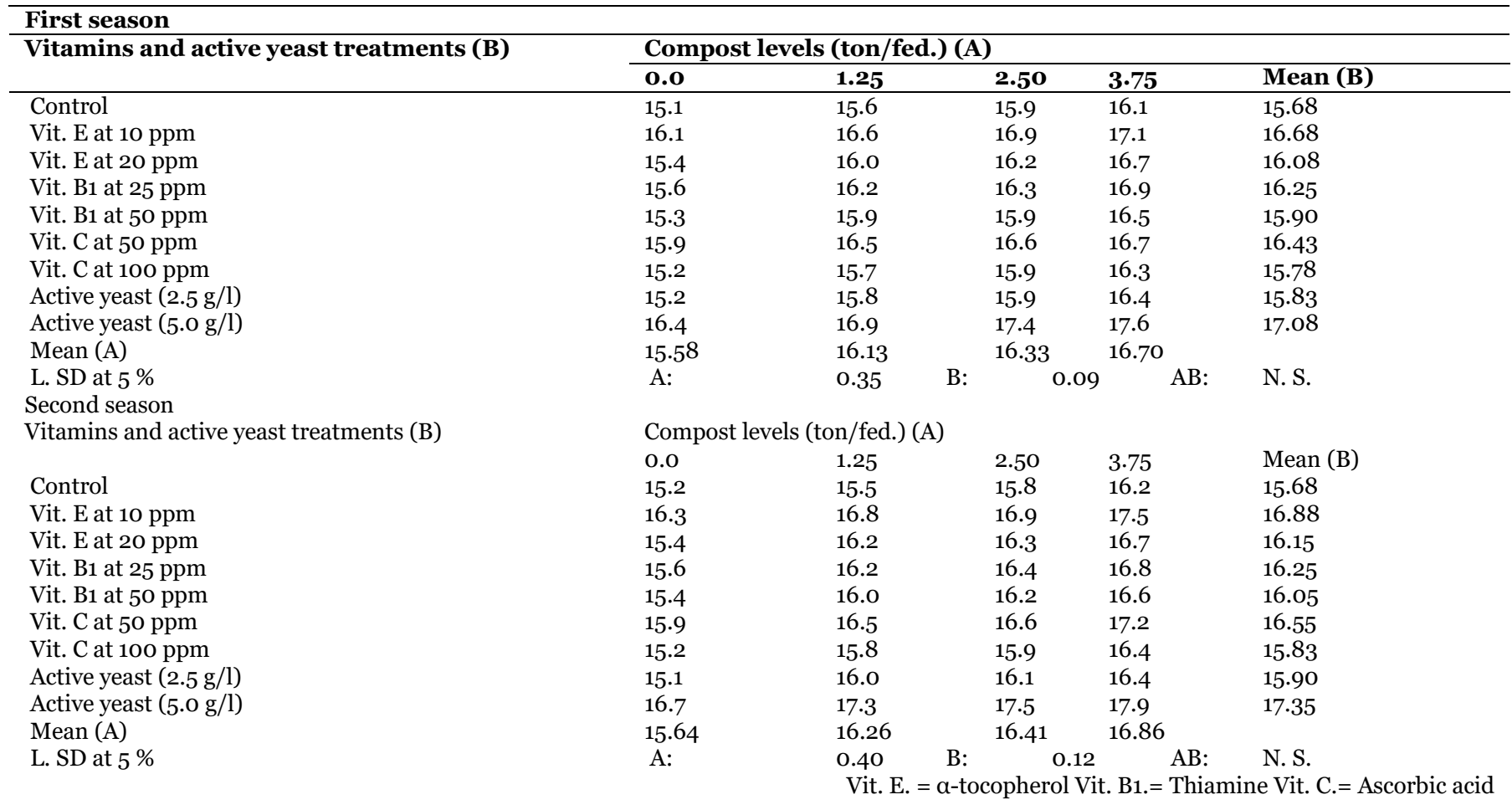


Data presented in table (11) indicated that each of the eight treatments were positively and significantly effective on promoting protein \% in the dry seeds of guar in the two seasons, over those of control. The best results were obtained due to the use of active yeast ( $5 \mathrm{~g} / \mathrm{l}$.) followed by vit. $\mathrm{E}$ at $10 \mathrm{ppm}$ then vit. $\mathrm{C}$ at $50 \mathrm{ppm}$ with significant differences between such three treatments in their capability in increasing the seeds percentage of protein. Similar results were obtained by [51] and [39] on Phaseolus vulgaris; [42] on Vicia faba and [40] on sugar beet, concerning the effect of active yeast. However, [68] on snap beans reported that vit. E had simulative effect on protein content. Also, [41] on Vicia faba; [69] on Saccharum spp and [70] on Pisum sativum concluded that application of vit. $\mathrm{C}$ increased total protein in the seeds.

The interaction between compost, active yeast and vitamins treatments was not significant for protein \% during both seasons as shown in table (11).

\section{CONCLUSION}

From the obtained results in this work, it could be recommended to supply Cyamopsis tetragonoloba Taub. plants with compost at 3.75 ton/fed., and spraying plants with either active yeast at $5 \mathrm{~g} / \mathrm{l}$. or ascorbic acid (vit. C) at $50 \mathrm{ppm}$ to improve guaran production., as well as, enhancing the values of some chemical constituents of guar plant under investigation condition.

\section{REFERENCES}

1. Thakure, C. (1975): Scientific Crop Production. Metropolitan Book. Co-PVT. Limited I, Nalaji Subhash Marg. Delhi, India.

2. Vinizky, I. and Ray, D. T. (1988): Germination of guar seed under saline and temperature stress. J. Am. Soc. Hort. Sci., 113:437-440.

3. Deraz, S. N. (1993): Biochemical studies on guar seeds (Cyamopsis tetragonoloba L.) and their flour incorporation in Balady bread making. Mounofia J. Agric. Res., 18 (1-1): 75-88.

4. El-Etriby, H. M.; Al-Khamy, A. F. and Shahein, N. M. (1994): Evaluation of guar and Leucaena gum preparation in the manufacture of yoghurt. Annals Agric. Sci., Moshtohor, 32 : 1635-1642.

5. Whistler, R. and Hymowitz, T. (1980): Guar: Production, Nutrition and Industrial Use. Purdue University Press, Lafayette, India 47907.

6. Dauda, S. N.; Ajayi, F. A. and Ndor, E. (2008): Growth and yield of watermelon (Citrullus lanatus) as affected by poultry manure application. J. Agric. Soc. Sci., 4:121-211.

7. Zheljazkov, V. D. and Warman, P. R. (2004): Sourceseparated municipal solid waste compost application to Swiss chard and basil. J. Environmental Quality, 33:542-552.

8. Fryer, M. J. (1992): The antioxidative effects of thylakoid vitamine E ( $\alpha$-tocophrerol). Plant Cell and Environment, 15:381-392.

9. Hess, J. L. (1993): Vitamin E, Alpha-tocopherol. In Antioxidant in Higher Plants. CRC Press Inc., Boca Raton, Florida, USA.

10. Strove, E. A. (1989): Biochemistry. First Published Eng. 1989. Revised from the 1986 Russian Ed. ISBN 5-03-000543-9, 348-355.

11. Hess, D. (1981): Plant Physiology. Narosa Publishing House, New Delhi, 1981, 11002, 2nd Ed., 78, 79, 160, 162, 205-208.
12. Samiullah, M. M.; Ansari, S. A. and Afridi, R. K. (1988): B-vitamins in relation to crop productivity. Ind. Rew. Life Sci., 8:51-74.

13. Refaat, A. M. and Balbaa, L. K. (2001): Yield and quality of lemon grass plants (Cymbopogon flexuous Stapt) in relation to foliar application of some vitamins and micro-elements. Egypt Journal of Horticulture, 28 : 41-57.

14. Blokhina, O.; Virdainen, E. and Fagersted, K. V. (2003): Antioxidant, oxidative damage and oxygen deprivations stress. A Review Ann. Boi., 91:179-194.

15. Nagodawithana, W. T. (1991): Yeast Technology. Universal Foods Corporation Milwaukee, Wisconsin Published by Van Nostrand Reinhold, New York. 273 pp.

16. Anderson, E. (1949): Endosperm mucilage of legumes. Occurrence and composition. Ind. Eng. Chem., 41:2887-2890.

17. Moran, R. (1982): Formula for determination of chlorophylls pigments extracted with N-N dimethylformamide. Plant Physiol., 69:1376-1381.

18. Fales, F. W. (1951): The assimilation and degradion of carbohydrates by yeast cells. J. Bio. Chem., 193:113124.

19. Wilde, S. A.; Covey, R. P.; Lyer, J. C. and Voigt, G. K. (1985): Soil and Plant Analysis for Tree Culture. Oxford, IBH. Publishing Co., New Delhi, India.

20. Champan, H. D. and Pratt, P. F. (1975): Methods of Analysis for Soil, Plant and Water Calif. Univ. Division of Agric. Sci., 172-174.

21. Cottenie, A.; Verloo, M.; Velghe, M. and Camerlynck, R. (1982): Chemical Analysis of Plant and Soil. Laboratory of Analytical and Agro Chemistry. State Univ., Ghent, Belgium.

22. Ranganna, S. (1978): Manual of Analysis of Fruit and Vegetative Products. Tata Mc Graw-Hill publishing company. Limited new Delhi, Second Reprinted, 634 pp.

23. MSTAT-C (1986): A Microcomputer Program for the Design, Management and Analysis of Agronomic Research Experiments (Version 4.0), Michigan Stat Univ., U. S.

24. Gomaa, A. M. and Mohamed, M. H. (2007): Application of bio-organic agriculture and its effect on guar (Cyamopsis tetragonoloba L.) root nodules, forage, seed yield and yield quality. World J. of Agric. Sci., $3:$ 91-96.

25. Patel, C. S.; Patel, J. B.; Suthar, J. V. and Patel, P. M. (2010): Effect of integrated nutrient management on clusterbean [Cyamopsis tetragonoloba L. Taub.] seed production cv. Pusa navbahr. Inter. J. of Agric. Sci., January to June, b : 206-208.

26. Abdalla, M. Y. A. (2009): Effect of organic, bio and mineral fertilization on growth, yield, oil productivity and chemical constituents of coriander plant. J. Agric. Sci. Mansoura Univ., 34 : 5195-5208.

27. Fernandez, L. F.; Reyes, V. V.; Martinez, S. C.; Salomon, H. G.; Yanez, M. J.; Ceballos, R. J. and Dendooven, L. (2010): Effect of different nitrogen sources on plant characteristics and yield of common bean (Phaseolus vulgaris L.). Bioresource Technology, 101:396-403.

28. Ng'etich, O. K.; Aguyoh, J. N. and Ogweno, J. O. (2012): Effects of composted farmyard manure on growth and yield of spider plant (Cleome gynandra). Int. J. of Sci. and Nature, $3: 514-520$. 
29. Aly, M. K.; Mohamed, M. A. H.; Attia, F. A.; El-Sayed, A. A. and Abd El-Gawad, M. H. I. (2007): Effect of some organic and biofertilization treatments on coriander plants. 2-Chemical composition. Proc. 1st Inter. Conf. Desert. Cultivation, Problem and Solutions, Minia Univ., 27-29 March 2007.

30. Ahmed, E. F. A. (2007): Evaluation of certain fertilizing programs on anise and black cumin plants. $\mathrm{Ph}$ D. Thesis. Fac. Assiut Univ. Egypt.

31. Abdou, M. A. H.; Abdalla. M. Y.; Helaly, A. and Mosaad, S. (2013b): Physiological studies on sage plant. Minia J. of Agric. Res. and Develop, 32 : 161186.

32. Abd-El-Naeem, L. M. A. (2008): Response of caraway plants to some organic and biofertilization treatments. M. Sc. Thesis, Fac. Agric., Minia Univ., Egypt.

33. Tanious, C. T. S. (2008): Effect of some organic fertilization treatments on fennel plants. M. Sc. Thesis, Fac. Agric., Minia Univ., Egypt.

34. Abdou, M. A. H.; Aly, M. K.; Attia, F. A.; Ahmed, E. T. and Al-Shareif, A. M. O. (2013a): Physiological studies on black cumin plant. The 1st Under Press Inter of Hort. Agric. Assuit, February 2013.

35. El-Sherbeny, S. E.; Khalil, M. Y. and Naguib, N. Y. (2005): Influence of compost levels and suitable spacings on the productivity of Sideritis monata L. plants recently cultivated under Egyptian conditions. Bulletin of Fac. Agric., Cairo Univ., 56 : 373-392.

36. El-Leithy, A. S.; El-Hanafy, S. H.; Ahmed, G. F.; Etman, M. A. and Ali, M. Y. (2007): Effect of compost, bio-fertilizer and active dry yeast on Origanum syriacum L. plants under Sinai conditions. J. Product and Dev., $12: 153-171$.

37. Abdel-Kader, A. A.; El-Keltawi, N.; Tawfik, A. A. and Khater, M. R. (2008): Growth, yield and quality of henna (Lawsonia alba Lam.) plant as affected by soil type and application of active dry yeast. Assiut J. of Agric. Sci., 39 : 143-165

38. Mady, M. A. (2009b): Effect of foliar application with yeast extract and zinc on fruit setting and yield of faba bean (Vicia faba L.). J. Biol. Chem. Environ. Sci., 4 (20:109-127.

39. Nasser, R. M.; Ahmed, Y. M. and Nassar, D. M. (2011): Effect of foliar spray with active yeast extract on morphological, anatomical and yield characteristics of kidney bean (Phaseolus vulgaris L.) Australian J. of Basic and Applied Sci., 5: 1071-1079.

40. Agamy, R.; Hashem, M. and Al-Amri, S. (2013): Effect of soil amendment with yeast as biofertilizers on the growth and productivity of sugar beet. African J. of Agric. Res., $8:$ 46-56.

41. El-Bassiouny, H. M. S.; Gobarah, M. E and Ramadan (2005): Effect of antioxidants on growth, yield, savism causative agents in seeds of Vicia faba L. plants grown under reclaimed sandy soils. J. Agric. Pakistan.

42. Abou El-Yazied, A. and Mady, M. A. (2012): Effect of boron and yeast extract foliar application on growth, pod setting and both green pod and seed yield of broad bean (Vicia faba L.). J. of American Sci., 8 : 517-533

43. Abd El-Aziz, N. G.; El-Quesni, F. E. and Farahat, M. M. (2007b): Response of vegetative growth and some chemical constituents of Syngonium podoplyllum L. to foliar application of thiamine, ascorbic acid and kinetin at Nubaria. World J. of Agric. Sci., $3:$ 301-305.

44. Ngoc Son, T.; Van Tnu, V.; Hong Man, L. and Hiraoka, H. (2001): Effect of organic and biofertilizer on quality, grain yield and soil properties of soybean under rice based cropping system. Japan Inter. Center for Agric. Sci., 9:55-61.

45. Solieman, T. H.; El-Khatib, H. A. and El-Araby, S. M. (2003): Effects of organic manure, mineral nitrogen and bio-fertilizer application on vegetative growth and chemical composition of pea (Pisum sativum L.). Zagazig J. Agric. Res., $30:$ 751-767.

46. Abd El-Aziz, M.; Pokluda, R. and Abdel Wahab, M. (2007a): Influence of compost, microorganisms and NPK fertilizer upon growth, chemical composition and essential oil production of Rosmarinus officinalis $\mathrm{L}$. Not. Bot. Hort. Agrobot. Cluj., 35 : 86-90.

47. Priya, S. and Elakkiya, R. (2012): Effect of organic and biofertilizers on growth and yield of Eclipta alba L. Int. J. of Pharm Tech Research, 4: 1703-1705.

48. Gendy, A. S. H.; Said-Al-Ahl and Mahmoud, A. (2012): Growth, productivity and constituents of roselle (Hibiscus sabdariffa L.) plants as influenced by cattle manure and biofertilizers treatments. Australian Journal of Basic and Applied Science, $6: 1^{-}$ 12.

49. El-Sayed, A. A.; Ali, M. K. and Abd El-Gawad (2002): Response of coriander plants to some phosphorus, zink and active yeast treatments Proc. 2nd Inter. Conf. Hort. Sci., Kafr El-Sheikh, Tanta Univ., Egypt, Sept. 10-12:434-446.

50. Naguib, N. Y. (2002): Yield and quality of lemongrass plants (Cymbopogon flexuous Stapf) as influenced by farmyard manure and foliar application of bread yeast. Annals of Agric., Sci., Ain Shams Univ., Cairo. $47: 859-873$.

51. El-Tohamy, W. A. and El-Greadly, N. H. M. (2007): Physiological response, growth, yield and quality of snap beans in response to foliar application of yeast, vitamin $\mathrm{E}$ and zinc under sandy soil conditions. Australian Journal of Basic and Applied Sci., 1 294-299.

52. Abdel-Hakim, W. M.; Moustafa, Y. M. M. and Gheeth, R. H. (2012): Foliar application of some chemical treatments and planting date affecting snap bean (Phaseolus vulgaris L.) plants grown in Egypt. J. of Hort. Sci. and Ornamental Plants, $4: 307-317$.

53. Talaat, N. B. (2003): Physiological studies on the effect of salinity, ascorbic acid and putrescine on sweet pepper plant. Ph D. Thesis, Fac, Agric., Cairo Univ., Egypt

54. El-Tohamy, W. A.; El-Abagy, H. M. and El-Greadly, N. H. M. (2008): Studies on the effect of putrescine, yeast and vitamin $\mathrm{C}$ on growth, yield and physiological responses of eggplant (Solanum melongena L.) under sandy soil conditions. Australian J. of Basic and Applied Sciences, 2 : 296-300.

55. Ismail, S. I. I. (2008): Anatomical and physiological studies on Nigella sativa, L. plant. Ph. D. Dess. Fac. Agric Mansoura Univ., Egypt

56. Mady, M. A. (2009a): Effect of foliar application with salicylic acid and vitamin $\mathrm{E}$ on growth and productivity of tomato (Lycopersicon esculentum Mill) plant. J. Agric. Sci. Mansoura Univ., 34 : 6735-6746.

57. Botros, W. S. E. (2013): Physiological studies on caraway plants. M. Sc. Thesis, Fac. Agric., Minia Univ. Egypt.

58. El-Mansi, A. A. Bardisi, H. and El-Robae, M. M. (2004): Comparative study on the effect of yeast, some vitamins, IBA and boron on growth and yield of tomato under sandy soil conditions. Zagazig J. Agric. Res., 31 (4A): 1409-1424.

59. Mohammad, O.; Bardisi, A. and El-Bassiouny, R. (2009): Effect of foliar spray with $\mathrm{Ca}, \mathrm{Mg}$ and vitamin 
B1 on the productivity and storability of snap bean grown in sandy soil. Zagazig J. Agric. Res., 36 : 41-62.

60. Menesi, F. A.; El-Mahrouk, E. M.; Sidky, M. A. and Rashed, N. M. (2002): Effect of bio-organic and chemical fertilization on dill, coriander and parsley, J. Agric. Sci., Mansoura Univ., 27 : 8337-8345.

61. Mohamed, H. A. and Gomaa, A. M. (2005): Faba bean growth and green yield and its quality as influenced by the application of bio-organic farming system. Journal of Applied Sciences Research, $1: 350-385$.

62. Gomaa, A. M.; Afifi, M. H. M.; Mohamed, M. F. and El-Dewiny, C. Y. (2010): Nodulation, growth characters and yield quality of faba bean cultivated in newly reclaimed sandy soil under bio-organic agriculture system. Inter. J. Academic Research, 2: 134-139.

63. Mahmoud, R.; El-Desuki, M.; Abdel-Mouty, M. and Ali, A. (2013): Effect of compost levels and yeast extract application on the pea plant growth, pod yield and quality. Journal of Applied Sciences Research, 9 : 149-155.

64. Abdou, M. A. H.; Attia, F. A.; Ahmed, E. T. and Abd El-Naeem, L. (2009): Response of caraway plants to some organic, antioxidants and biofertilization treatments. Proc. $4^{\text {th }}$ Inter. Environ. Conf., Mansoura Univ. on Environmental and Healthy Safety, 28-29 October, 2009, p: 109-119.
65. Al-Shareif, A. M. O. (2012): Physiological studies on black cumin plant. Ph. D. Thesis. Fac. of Agric. Minia Univ. Egypt.

66. Shafeek, M. R.; El-Zeiny, O. A. and Ahmed, M. E. (2004): Pigeon pea (Cajanus cajan) growth and yield as affected by the interaction between bio and organic fertilizers. Annals of Agricultural Science (Cairo), 49 : 619-630.

67. Maheshbabu, H. M.; Hunje, R.; Patil, N. K. B. and Babalad, H. B. (2008): Effect of organic manures on plant growth, seed yield and quality of soybean. Karnataka J. Agric. Sci., 21 : 219-221.

68. Nour, K. A. M.; Mansour, N. T. S. and Eisa, G. S. A. (2012): Effect of some antioxidants on some physiological and anatomical characters of snap bean plants under sandy soil conditions. New York Sci. J., 5 : 1-9

69. Batool, E.; Ahmed, S. and Faheem, A. (2012): Effect of exogenous application of ascorbic acid on antioxidant enzyme activities, proline contents and growth characters of Saccharum spp. hybrid cv. HSF-240 under salt stress. Turk J. Biol., 36 (2012): 630-640.

70. Gheeth, R. H. M.; Moustafa, Y. M. M and AbdelHakeem, W. H. (2013): Enhancing growth and increasing yield of peas (Pissum sativum, L.). by foliar application of ascorbic acid and cobalt chloride. J. Novel Applied Sciences, 2 : 106-115. 